\title{
Património Urbano: por onde passa a sua salvaguarda e reabilitação? Uma Breve visita à Mouraria
}

\author{
Marluci Menezes*
}

\begin{abstract}
$\mathrm{R}$ frequência, ideias ou perspectivas que defendem a importância em reabilitar ou revitalizar determinados valores socioculturais considerados como tradicionais, sem, contudo, se reflectir profundamente sobre a articulação entre tais orientaçø̃es e as dinâmicas socioespaciais dos territórios. Toma-se como referência um estudo antropológico desenvolvido num bairro típico e popular de Lisboa - Mouraria - para reflectir sobre como no processo de produção e construção social do espaço, a idealização e a sobrevalorização de determinadas tradiçẽes que procuram apoiar-se num passado pensado como histórico - mas que é socialmente inventado e constantemente reinventado - tanto pode promover a dinamização sociocultural como, indirectamente, potenciar o risco da produção de espaços urbanos segregados.
\end{abstract}

Palavras-chave: património urbano e cultural; tradição, reabilitação; revitalização cultural.

\section{Breves (re)considerações sobre a intervenção na cidade existente}

Quando se pretende reflectir sobre a intervenção na cidade existente ${ }^{1}$, é recorrente evocar a significativa evolução operada ao nível dos seus processos e conceitos subjacentes desde finais dos anos 60 do século $\mathrm{xx}^{2}$. A partir desse período, configura-se uma perspectiva de intervenção que, estimulada pelo debate sobre os centros históricos, se alicerça numa postura crítica em relação às práticas precedentes, as quais se pautavam pela conservação e restauro de elementos isolados do património arquitectónico, bem como pelo recurso à demolição e renovação sistemática do tecido edificado dos centros urbanos. No seu já clássico texto "Notas sobre a intervenção na cidade existente" (1985), Nuno Portas refere que essa evolução teve como resultado a conjugação de diversificados vectores, entre os quais destaca:
- A ampliação do conceito de património arquitectónico - antes apenas identificado com o monumento - que passa não apenas a abarcar sequências mais amplas do tecido urbanizado e construído (o quarteirão, a praça, conjuntos característicos), como também a integrar as dimensẽes físicas e sociais dos contextos de intervenção no conjunto urbano. Desta forma, progressivamente, a noção de intervenção na cidade existente passa a considerar "como um dado económico e cultural a estrutura e forma da cidade, dos seus bairros e centros, dos seus edifícios, ruas ou quintais e também como um dado social a trama de relaçães sociais e de actividades que aquelas estruturas físicas suportam e reflectem" (Portas, 1985: 8).

- O reconhecimento por parte dos órgãos da administração local da importância do "stock construído (para além do valor monumental)", como elemento a ter em conta na programação

\footnotetext{
Doutorada em Antropologia Cultural e Social, Investigadora do Núcleo de Ecologia Social (NESO) do Laboratório Nacional de Engenharia Civil (LNEC). Cøntacto: marluci@lnec.pt

' Segundo Nuno Portas, por intervenção na cidade existente entender-se-á “o conjunto de programas e projectos públicos ou de iniciativas autónomas que incidem s•bre os tecidos urbanizados dos aglomerados, sejam antigos ou relativamente recentes, tendo em vista: a sua reestruturaçāo ou revitalização funcional (actividades e redes de serviços); a sua recuperaçāo ou reabilitaçāo arquitectónica (edificação e espaços nāo construídos,

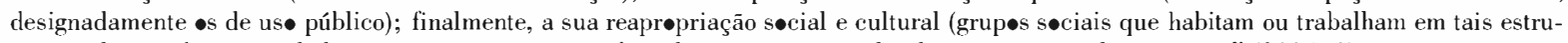
turas, relaçōes de propriedade e troca, actuaçōes no âmbito da segurança social, educação, tempos livres, etc.)." (1985: 8).

${ }^{2}$ Um recente trabalho de Vargas e Castilho (2006) propõe-nos uma análise sistemática - em termos de objectiv•s, estratégias e resultadøs - dos processos de intervençāo em centros urbanos desde o fim da Segunda Guerra Mundial até os dias de hoje.
} 
das necessidades habitacionais tendo em vista uma melhor "redistribuição e plena utilização do parque imobiliário" (Portas, 1985: 9).

- O surgimento de movimentos sociais nos bairros históricos, que se opunham à expulsão das famílias residentes em decorrência da intenção de "saneamento das condições ambientais", ao mesmo tempo que cientistas e técnicos da intervenção social se deparam com um potencial de mobilização e auto-organização sociolocal em prol da (re)valorização dos contextos. Sendo ainda de referir que, paralelamente, se assiste à emergência de uma atenção votada, ao nível da intervenção, às transformações observadas na dinâmica económica e sociodemográfica destes contextos (Portas, 1985: 9).

- A emergência de uma crise de conceitos e práticas na arquitectura urbana em decorrência do insucesso das urbanizações dos anos 60 do século Xx, fazendo com que os profissionais voltassem a aprender com a cidade, "influenciando as autoridades locais para privilegiarem intervenções fragmentárias ou sistemáticas de melhoria do existente" (Portas, 1985: 8).

A dinâmica de intervenção na cidade existente continuou a evoluir e, nesse sentido, os dias de hoje não espelham necessariamente as mesmas condicionantes - socioeconómicas, culturais, urbanas, políticas e administrativas sobre o qual recaem as observações acima referidas. Mas, estas mesmas observações permitem sublinhar: 1) que a intervenção no património, outrora associada à protecção de edifícios isolados, passou a ser considerada do ponto de vista de tecidos urbanos mais extensos; 2) a importância que adquire a perspectiva de (re)adequação desse património - em termos de usos, necessidades e imagens ${ }^{3}$; 3) a integração das dimensões sociais, para além das físicas, nos processos de intervenção. A maior abrangência e profundidade dos sentidos da intervenção na cidade existente, assume-se simultaneamente como manifestação e motores das dinâmicas de (re)invenção do património ${ }^{4}$.

\section{$0 \ll$ re» em questão}

Ao conjunto de programas e projectos de intervenção urbana viria gradualmente a associar-se um conjunto de noções que, começadas por re, expressam aquilo que se considera importante fazer pelo património urbano: reabilitar, revitalizar, reconverter, regenerar. Segundo Nuno Portas (2003: 75), na sucessão destes vocábulos insinua-se um debate de mais de meio século "desde que duas famosas Cartas, ambas chamadas de Atenas, propunham políticas quase opostas - restaurar ou renovar - que se podiam então traduzir por conservar ou substituir e ainda por integrar ou contrastar (opor)".

Apresenta-se em seguida uma breve sistematização referente aos modos como, desde finais dos anos 60 do século Xx, tais noções têm sido aplicadas no âmbito da intervenção sobre o património urbano.

\footnotetext{
3 A intervenção na cidade existente implica o desencadear de "operações cirúrgicas mais ou menos profundas sobre os tecidos herdados com a consequente marca formal de quem hoje as faz e as usa" (Portas, 1985:9).

${ }^{4}$ Por não ser objecto da reflexão deste texto, aqui não se aprofunda a discussão sobre as questões relacionadas com as dinâmicas de reinvenção do património. No entanto, o interesse por essa temática não nos é alheio e, nesse sentido, por ora, chama-se a atenção para alguns trabalhos sem, contudo, ser-se exaustivo nas referências aqui feitas. Françoise Choay (1992) reflecte acerca dos processos sociais e urbanos de invenção do património urbano na Europa desde o século XIX. Alain Bourdin $(1979,1984,1996)$ discute as lógicas sociais e urbanas de reinvenção do património, sobretudo a partir das políticas de reabilitação, conservação, requalificação e renovação urbanas. Ao discutir de forma crítica as dinâmicas de reinvenção do património urbano, Henry Pierre Jeudy (2005) associa-as aos processos de patrimonialização e estetização urbanas. Observe-se que Carlos Fortuna (1997, 1999, 2002), Aníbal Frias e Paulo Peixoto (2002) têm reflectido, em termos de contexto português, numa óptica similar a de Henry Pierre Jeudy, associando as suas reflexões a uma discussão abrangente sobre a relação patrimonialização / / turistificação das cidades. Coordenado por Henry Pierre Jeudy será também interessante consultar o trabalho "Patrimoines en Folie" (1990), no qual se aborda as questões da gestão, transmissão, conservação e continuidade do património. Sobre as lógicas políticas ligadas às dinâmicas de reinvenção do património é interessante consultar Marc Guillaume (1980) e Gerard Althabe (et. al., 1984). Firmino da Costa (1999), por seu lado, na análise que faz sobre o bairro de Alfama, em Lisboa, desenvolve uma interessante reflexão sobre o par invenção do património / / invenção das tradições.
} 
Noções

\section{Reabilitação / \\ / recuperação}

\section{Revitalização /} / ReUTilizaÇão

\section{REgeneração}

\section{Reanimação / / Reconversão}

\section{Significados MaIS CARACTERísticos}

Na sua origem o termo reabilitar está associado à reaquisição ou restabelecimento de direitos por parte de alguém que deles havia sido privado, nomeadamente no âmbito judicial. No entanto, o termo abarca ainda uma outra vertente reportada à aç̧ão de recuperar em contexto público ou privado de relação "a estima e a consideração" (Choay e Merlin; in Vasconcellos e Mello, 2006:58). No âmbito da intervenção urbana, as lógicas da reabilitação ultrapassam a simples melhoria das condições de habitabilidade, destacando-se a preocupação em defender-se a continuidade residencial dos moradores mais carentes, bem como a permanência dos comerciantes e artesãos com maiores dificuldades de solvência económica (Portas, 2003). Reabilitar sugere uma acção mais ampla que, segundo Luz Valente Pereira (1986) se oferece como oportunidade de reencontro com o bom conceito que a cidade detinha, assim recuperando a estima pública.

Nos processos de intervenção urbana inspirados pela ideia de revitalização, assume-se a premência da necessidade de recomposição da mistura de actividades e de uma maior diversificação etária, cultural e económica da população residente ou activa, de áreas mais alargadas e, como tal, mais heterogéneas em termos históricos e estéticos (Portas, 2003). O sentido da ideia de revitalização aplica-se também ao correlacionar de intervenções de recuperação de âmbito pontual conforme decorre nos edifícios, com aquelas de âmbito mais geral e que se referem à reabilitação das estruturas sociais, económicas e culturais locais com o objectivo de melhorar a qualidade global dos contextos de intervenção (Aguiar, 1993). A perspectiva de revitalização propõe novos usos ao tecido edificado, ou melhor dizendo, uma reutilização do mesmo e que, por seu lado, também se relaciona com uma perspectiva de requalificaçã $o^{5}$.

Termo que ganha força no início dos anos 80 do século xx e que se inspira no "processo que ocorre num organismo vivo quando este demonstra a capacidade de reconstituir um seu tecido danificado, repondo um equilíbrio funcional que havia sido perturbado" (Vilares, 2003:100). Nesta metáfora que "compara a trama de um tecido da pele ao tecido urbano", assume-se como implícita a preocupação vocacionada para revitalização/recuperação dos contextos locais do ponto de vista económico (Vasconcellos e Mello, 2006:60). Normalmente este termo está associado às reurbanizações mais recentes e identificadas com um modelo económico neoliberal, onde a privatização de áreas públicas e a gestão do ambiente através de parcerias mistas (público e privado) prevalecem.

Noções que reflectem algumas contradições das intervenções precedentes da década de 80 do século Xx, as quais decorrem das críticas aos processos de gentrification, ao aumento da actividade turística e da terciarização (marcada sobretudo pelas actividades de restauração e de diversão nocturna) dos centros urbanos. Reivindica-se a necessidade de um novo olhar votado aos problemas das acessibilidades, das infra-estruturas, dos equipamentos locais, bem como da necessidade de alterações significativas na tipologia e construção dos edifícios de modo a que fosse possível a sua adaptação a novos usos. Por outro lado, as noções de reanimação e reconversão dos contextos sustentam a necessidade de mudanças significativas nos espaços públicos, muitas vezes implicando para tal um incremento de parcerias público e privadas no âmbito das acções e das dinâmicas de gestão implementadas. Desde então, as intervenções feitas têm permitido uma maior competitividade entre as cidades, nomeadamente no que concerne às acessibilidades, serviços, animação cultural e à qualidade do ambiente (Portas, 2003).

\footnotetext{
Entenda-se por requalificação um conjunto de intervenções múltiplas com o intuito de (re)valorizar as potencialidades sociais, culturais, económicas e funcionais dos contextos de intervenção, melhorando as condições do tecido edificado, de forma a promover a qualidade de vida.
} 
As noções acima referidas convivem entre si, alcançando alternadamente maior ou menor preponderância em determinados períodos ${ }^{6}$. Associadas a modos de intervenção no/sobre o espaço estas noções acentuam também a importância de reflectir sobre a dimensão temporal enquanto recurso de construção e legitimação desses mesmos modos de actuação. Nas noções acima referidas encontra-se implícita a ideia de capacitar a cidade existente, sobretudo as suas áreas degradadas e mais decadentes, em termos de uma vitalidade social, económica e cultural. O caminho para esta capacitação passa, no entanto, por uma revisitação às preexistências - sendo que o re insinua, neste âmbito, uma promessa de reordenação do presente através do reencontro com o passado. Segundo Yañez Casal (1994), essa busca pelas preexistências reflecte a necessidade de reencontro com o mito de fundação das nossas sociedades. De acordo com o autor, a reordenação de que se fala reflecte uma inversão na relação com o passado, que é accionada através da estratégia de criação de uma nova mediação, sobretudo, fundamentada no património e no discurso que o sustenta. Desse modo, as coisas que se identificavam com o passado se transformam em objectos de significação, reassumindo uma outra função: a simbólica; e adquirem um novo estatuto: ser património. Neste sentido, ressalta-se que numa reflexão sobre "as culturas como património", José Gonçalves (2005) refere que "o sentido fundamental dos patrimónios consiste talvez em sua natureza total e em sua função eminentemente mediadora" $"$.

Ao pretender-se reavivar - reabilitar, revitalizar, reconverter, regenerar - algum aspecto de âmbito físico, cultural, social ou económico, parte-se do princípio de que, no contexto de intervenção, existem determinados elementos e/ou condições que possibilitam a viabilização e concretização de tal intenção. Mas através de que critérios se procede à análise e à capacitação de tais elementos? Esses critérios, como refere Firmino da Costa (1999:34), "são tudo menos consensuais". De facto, "de entre as sucessivas camadas da longa e continuada produção do espaço urbano local, são seleccionados certos elementos a que se atribui um carácter mais autêntico do que aos outros. E os critérios de selecção que são eminentemente de significado social, e que radicam (...) nos sujeitos que os accionam, são concebidos como emanando de uma supostamente intrínseca genuinidade diferencial dos objectos - como se certas obras da acção humana, ou certas épocas fossem portadoras de uma essencialidade ontológica maior do que as outras". Se entendermos que a ideia de tradição evoca "um conjunto de orientações valorativas consagradas pelo passado" (Oliven, 1992:21), passado esse que, entretanto, é quotidianamente inventado (Hobsbawn e Ranger, 1996), coloca-se o problema de tentar perceber como operam essas construções sociais que ligam as tradições às identidades sociais e espaciais.

Neste sentido, como acentua Moragas (2001), importa reflectir sobre a complexidade da noção de autenticidade, nomeadamente quando o seu significado tem vindo a adquirir um estatuto que extrapola a sua ligação única ao património construído, abarcando outras esferas do real, associadas designadamente às dimensões sociais e culturais dos contextos locais ${ }^{8}$.

\footnotetext{
${ }^{6} \mathrm{Na}$ literatura não há uma uniformidade de critérios no que se refere à nomenclatura associada aos tipos de intervenção na cidade existente, registando-se a permanência de um espectro de designações que, não raras vezes, sobrepõem - sob designações semelhantes - objectivos e estratégias de intervenções distintos. Para este problema concorre também a própria convivência temporal de diferentes ópticas de intervenção que sucessivamente ora reivindicam proximidades ou dissemelhanças entre si. Por exemplo, Vargas e Castilho (2006) no sentido de compreender os processos de intervenção, sobretudo aqueles que se operam nos centros urbanos, procedem à delimitação de três períodos característicos: Renovação Urbana (1950-1970); Preservação Urbana (1970-1990); Reinvenção Urbana (1980-2000). Contudo, as autoras salientam que esses períodos não são rígidos nas suas delimitações, nem tão pouco mutuamente exclusivos.

${ }^{7}$ Num texto anterior, José Gonçalves (2002: 121-122) referiu: “os patrimónios culturais são estratégias por meio das quais grupos sociais e indivíduos narram sua memória e sua identidade, buscando para elas um lugar público de reconhecimento, na medida mesmo em que as transformam em património. Transformar objectos, estruturas arquitectónicas e estruturas urbanísticas em património cultural significa atribuir-lhe uma função de representação, que funda memória e identidade. Os diálogos e as lutas em torno do que seja o verdadeiro património são lutas pela guarda de fronteiras, do que pode ou não receber o nome de património, uma metáfora que sugere sempre unidade no espaço e continuidade no tempo no que se refere à identidade e memória de um indivíduo ou de um grupo. Os patrimónios são, assim, instrumentos de constituição de subjectividades individuais e colectivas, um recurso à disposição de grupos sociais e seus representantes em sua luta por reconhecimento social e político no espaço público".

${ }^{8}$ Ao apoiar-se em autores como Theodor W. Adorno (no qual se destaca o trabalho: "The jargon of authenticity") e Richard Handler, José Gonçalves (1988) reflecte sobre a relação entre "autenticidade, memória e ideologias nacionais" e o "problema dos patrimónios culturais", dando-nos conta sobre como a categoria autenticidade é recorrentemente referida nas ideologias nacionais, étnicas e, inclusivamente, no próprio discurso dos cientistas sociais. A autenticidade é também um tema expressivo na obra de Walter Benjamin sobre a sua relação com as
} 
A importância patrimonial dos contextos assenta, além da atenção conferida aos aspectos arquitectónicos, na construção social de uma especificidade que advém de determinadas formas culturais e simbólicas tidas como manifestamente peculiares e expressivas dos mesmos, alcançando por esse meio o estatuto de tradição, eventualmente, a salvaguardar e reavivar. Por detrás da tentativa de relacionar uma determinada tradição cultural com um contexto específico, existe uma espécie de reforço das dimensões que permitem justificar a própria historicidade do contexto, fundeada em três hipóteses, a de que "as formas de identidade cultural de um grupo coincidem necessariamente com as formas de identidade cultural relativas aos espaços em que ele vive"; a ideia segundo a qual "as relações entre identidade cultural e memórias sociais se estabelecem necessariamente com base num grupo produtor e portador das duas; a hipótese de que a transmissão cultural se faz necessariamente por continuidade social, de geração em geração, nesses grupos portadores de memórias e identidades partilhadas" (Costa, 1999: 51). Não se contesta, como sublinha Firmino da Costa, a importância de considerar esses processos na construção social da realidade dos/sobre os contextos locais - o que se contesta é o "carácter necessário e suficiente" das hipóteses atrás referidas. Numa mesma linha de raciocínio, não está em causa a existência de formas culturais e sociais localmente reconhecidas como tradições; o que nos parece importante discutir respeita às "operações de selecção" (Costa, 1999) que subjazem à construção das intervenções sobre o património, designadamente aquelas acções sustentadas pelos vocábulos iniciados por re para assim reavivar ou recuperar uma determinada genuinidade cultural localizada num tempo passado.

Mas, existirão tradições mais genuínas que outras? Tomando como referência os designados bairros populares de Lisboa, de que se fala quando se faz referência à recriação da tradição? Pretende-se recriar a genuinidade de determinadas manifestações socioculturais? Por exemplo, ao considerar-se o fado como algo característico destes bairros, o que fazer com todo o conjunto de personagens e dinâmicas atribuídas ao próprio contexto socio-ecológico que lhe deu fama - onde pontuam memórias reportadas à prostituição, à miséria, ao alcoolismo, à malandragem? Reconstitui-se? Recupera-se apenas o que interessa? Mas o que interessa? Quem dita o que deve ser protegido e/ou revitalizado? Que tradição pura e/ou genuína se quer conservar, recuperar, revitalizar, reanimar e/ou reabilitar? Por outro lado, em que medida é que a ideia de conservar e reabilitar a autenticidade de uma cultura e de uma tradição, entra em contradição com a própria dinâmica das sociedades? Repare-se, conforme referido por Vasconcellos e

técnicas de reprodução. Para Benjamin, um objecto autêntico está identificado com a ideia de originalidade, daí possuir uma aura que se constrói por "uma relação genuína com o passado"; e um objecto inautêntico seria a cópia ou a reprodução de um determinado original (in Gonçalves, 1988: 265). Carlos Fortuna, por seu lado, retoma essa perspectiva de Benjamin para introduzir uma discussão sobre o fenómeno do turismo e da estetização dos lugares e, nesse sentido, de forma a problematizar e complexificar a questão, reposiciona a discussão sobre a "natureza da autenticidade" dos "contextos histórico-monumentais (ou culturais num sentido estrito)" (Fortuna, 1999: 64-66) por relação à "voracidade com que a indústria do turismo objectifica e mercadoriza as cidades e os monumentos, a natureza e as paisagens, os costumes e os sentimentos" (Fortuna, 1999: 57). No desenvolvimento da sua reflexão, Carlos Fortuna chama a atenção para as ambiguidades da perspectiva defendida por Walter Benjamin quando aplicada à cidade; e evidencia o paradoxo resultante da globalização: a difusão e banalização de uma dada singularidade urbana, assente no entanto no reconhecimento de que um dado contexto é "único e localmente valioso". Na sua explicitação, o autor cita o exemplo da cidade de Évora como Património da Humanidade. Abel Albet i Mas discute como a cultura, nas suas diferentes acepções, vem sendo apropriada e manipulada pelas "estratégias de transformação social e urbanística das cidades" (Mas, 2004: 15), desse modo promovendo a mercantilização dos lugares e a negação da autenticidade dos mesmos. Francesc Muñoz, por seu lado, retoma a discussão sobre a cultura como instrumento e estratégia de transformação urbana para assinalar um processo que o autor chama de urbanalização e que, na sua generalidade, refere-se ao "triunfo absoluto do comum" por contraposição a minimização da presença da complexidade e das diferenças (Muñoz, 2004: 27). Tais discussões respeitam ao que outros autores têm considerado como um processo de transformação da cultura num instrumento de revitalização urbana, tornando-se inclusivamente o motor do ideal de desenvolvimento económico a ser promovido no âmbito do que se poderia designar como culturalismo de mercado (Otília Arantes; in Jacques, 2003) ou ainda de culturalização do planeamento e da cidade (Vaz, 2004). Por outro lado, tais questões permitem assinalar aquilo que Moragas (2001) considera como um problema que se coloca relativamente à forma como tem sido discutida a questão da autenticidade cultural dos contextos urbanos considerados património. Neste sentido, o autor se refere ao problema do eventual congelamento de determinadas condições de vida e da espectacularização de determinadas formas culturais, observando duas situações mais recorrentes: 1) a suposição de uma determinada autenticidade baseada na pobreza e na desigualdade; 2) a suposição de uma determinada autenticidade baseada no simulacro. Não menos importante aqui será, uma vez mais citar, José Gonçalves (2005: 31) que, ao utilizar a noção de "cultura autêntica" conforme discutida por Edward Sapir, reflecte sobre a "utilidade dessa noção (...) como um instrumento conceptual para interromper todo e qualquer processo de definição e objectivação de formas culturais". Neste sentido, o autor salienta que "a cultura autêntica é precisamente o que escapa de toda e qualquer definição, classificação e identificação precisa e objectificadora, tal como ocorre nos discursos do património cultural em seu sentido moderno, especialmente quando articulados por agências do Estado. São exactamente as formas de cultura autêntica que necessariamente escapam das redes desses discursos" (Gonçalves, 2005: 31). 
Mello (2006: 64), que “implícita em todos os REs, está a manutenção da cultura local. Seria essa cultura possível de ser mantida, se o próprio conceito de cultura leva a entendê-la como um processo dinâmico e mutável no tempo?".

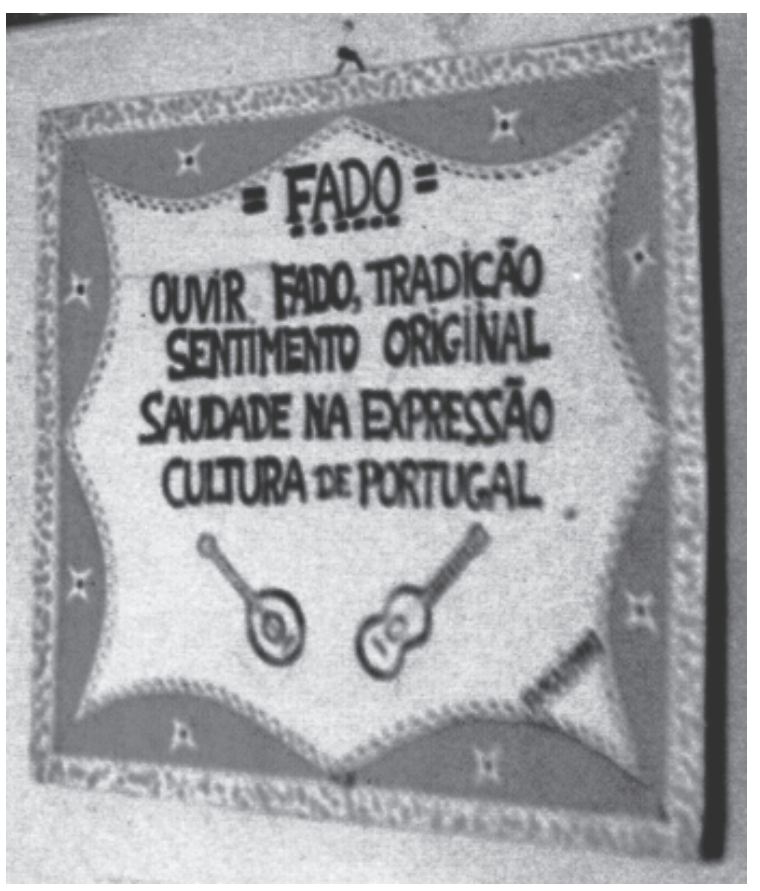

Quadro poema da autoria do poeta Baguinho

Foto de: Marluci Menezes

Do confronto com perspectivas de intervenção urbana que se apoiam no prefixo re para aludir àquilo que é necessário fazer pelo património, importa questionar em que medida nelas se encontra plasmada uma reflexão aturada - e em que medida informada - sobre as múltiplas implicações que as intenções de reabilitar, revitalizar, redinamizar, requalificar, regenerar e reconverter, podem ter nas dinâmicas socioculturais.

A cidade existente define-se não apenas pelas especificidades da sua fisionomia arquitectónica e urbana, mas também pelos modos como determinadas dinâmicas socioculturais se encontram territorializadas, continuadamente assistindo-se a processos de (re)produção e (re)configuração das mesmas. Nestes processos, e no que se refere à construção da visibilidade social dos contextos locais participam representações endógenas e exógenas. Contudo, conforme salientado por Firmino da Costa (1999: 51) para o caso de Alfama, as representações simbólicas que sustentam a "visibilidade social alargada" do bairro são sobretudo elaboradas "por agentes e processos exógenos" aos "colectivos sociais nele localmente inseridos". Uma questão tão mais importante quando se regista que as representações simbólicas que sustentam as intervenções apoiadas num ou noutro vocábulo iniciado por re não são propriamente construídas pelos colectivos sociais inseridos nos contextos locais de intervenção, decorrendo sim de dinâmicas protagonizadas por agentes e processos, muitas vezes, exógenos.

Procuraremos discutir sobre alguns aspectos até aqui referidos, a partir da revisitação de um trabalho desenvolvido, entre os anos de 1997 e 2001, no bairro da Mouraria em Lisboa, no qual se investigou e reflectiu sobre as questões socioculturais subjacentes aos dilemas, contendas e conflitos simbólicos subjacentes ao processo de construção de imagens identitárias do bairro (Menezes, 2004).

\section{Revisitando o bairro da Mouraria em Lisboa}

\section{Uma breve aproximação ao contexto}

A Mouraria é um bairro que se encontra entre o Largo do Martim Moniz e a Graça, ocupando as vertentes Norte e Poente da colina do Castelo de São Jorge em Lisboa. Grande parte do bairro ainda faz parte de uma Área de Reconversão Urbanística que data de 1985, encontrando-se o núcleo central do bairro na Freguesia do Socorro.

Mouraria foi a designação atribuída ao arrabalde destinado aos mouros após a reconquista cristã da cidade (em 1147), datando de 1170 o foral que instituiu a comuna moura. De notar que, embora tais acontecimentos façam parte quer da história do bairro quer como da própria cidade, existe também um mito que, explicando a viabilização da reconquista cristã, situa a origem da mouraria de Lisboa. Fala-se no mito (ou lenda) do Martim Moniz, um soldado que, durante o Cerco de Lisboa ficou preso numa das portas da Cerca Moura, desse modo, auxiliando a entrada dos cristãos na área ainda ocupada pelos mouros. A par da sua origem formal, a fundação do bairro encontra-se desta forma também associada a uma espécie de mito de origem.

Inicialmente, o arrabalde era muralhado e a sua entrada facultada por portas com horários de abertura e fecho. A mouraria era um gueto, isolado 


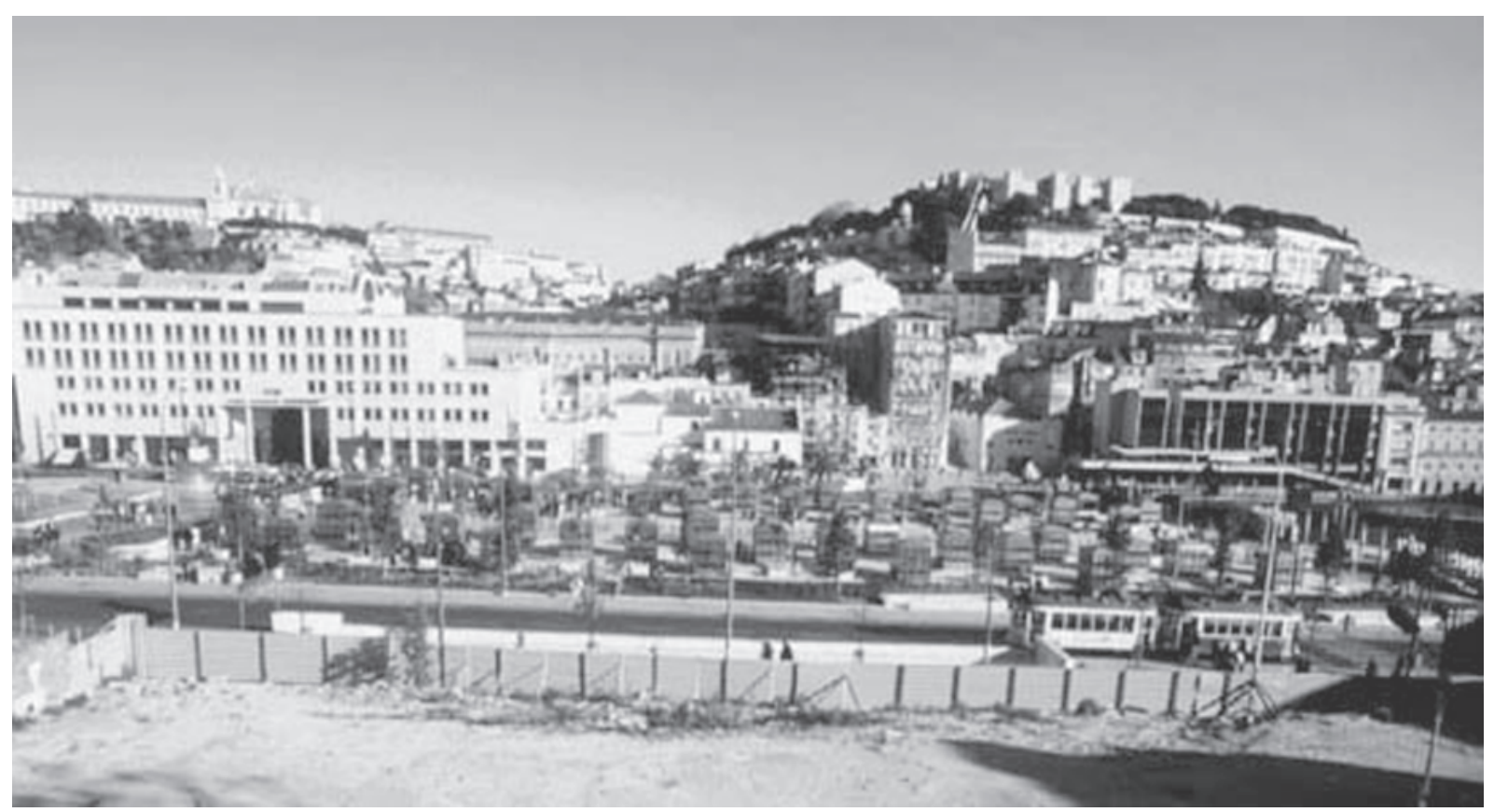

Vista da Mouraria a partir da Colina de Sant'Ana Foto de: Marluci Menezes

do resto da cidade. Mas devido à intensa actividade económica que ali se desenvolvia - sobretudo comercial e artesanal - o arrabalde acabou por atrair segmentos cristãos da população, que viriam a instalar-se na envolvência próxima do bairro, dando-se início a um convívio profissional e de vizinhança que, em Lisboa, segundo consta, naquela fase da história da cidade, somente se verificou neste segmento do espaço urbano (Barros, 1998). Indubitavelmente, admitindo que cristãos e muçulmanos correspondiam a identidades étnicas distintas, é pertinente falar na existência de um convívio multiétnico, o qual incrementou a expansão do bairro pelas áreas vizinhas.

O bairro sempre se caracterizou pela sua pobreza e precariedade habitacional, atraindo ao longo da sua história, sobretudo, segmentos da população com dificuldades socioeconómicas. Tais características ficariam particularmente evidenciadas a partir do século XV, com a crescente tendência da cidade voltar-se para o rio, e com o aumento da população da cidade em função de movimentos migratórios oriundos das zonas rurais do País. Muitos desses migrantes vinham para os bairros populares da cidade, entre os quais a Mouraria. A partir do século XVIII e até meados do século XX, assistiu-se a um vertiginoso aumento populacional da cidade, pelo que bairros como Alfama e Mouraria atingiram as suas capacidades de ocupação e, em decorrência da sua precariedade socioeconómica e funcional passaram, juntamente com outros bairros, a ser conhecidos como os bairros pobres da cidade (Cordeiro, 1997).

Um dos fenómenos que despontou da dinâmica de recomposição e reconfiguração urbana, traduzida nos elevados índices de concentração populacional nos bairros antigos de Lisboa e nas mudanças demográficas, sociais e culturais provocadas pelas vagas migratórias de finais do século XIX, foi a invenção daquilo que posteriormente passou a ser chamado tradições populares (Cordeiro, 1997). E, algures no século XIX, também a Mouraria foi socialmente construída como um bairro que detinha algumas tradições, encontrando-se esta fundação no meio de uma complexa rede de elementos culturais, sociais, históricos, urbanos e rurais, sonhos, mitos e representações. No sentido de descobrir os precedentes que justificam essa tipicidade e tradição da Mouraria, torna-se necessário ir ao encontro de um sistema de representações que se reporta a um outro sistema de representações (Barthes, 1987). Fala-se aqui no mito da Severa uma bela e formosa prostituta que ficou conhecida como uma grande cantora de fado - e cuja função simbólica é bastante próxima de um mito de origem. 


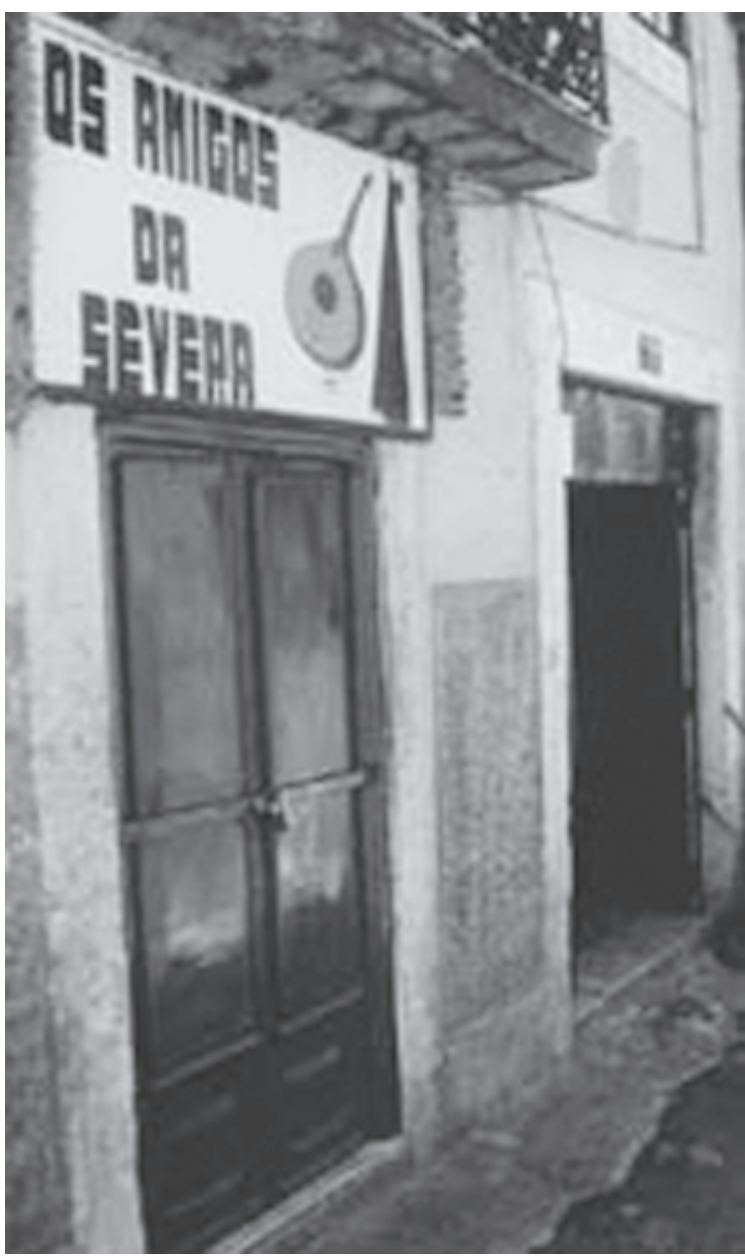

Tasca "Os Amigos da Severa" (núcleo da Mouraria) Foto de: Marluci Menezes

A par de um processo de emblematização, o bairro continuava a ser atravessado por um processo de estigmatização e segregação socioespacial, já que a par da pobreza e miséria que ali prevaleciam, a Mouraria também ficaria conhecida como um contexto propício à prostituição, à vadiagem, ao alcoolismo.

Em termos urbanísticos, o bairro praticamente manteve-se inalterado até à segunda metade do século XIX. Nem o terramoto de 1755, que atingiu grandes áreas da cidade, provocou destruições significativas na Mouraria. Portanto, desde meados do século XIX, preconizava-se a destruição do bairro, mas as alterações mais significativas durante este período referem-se à abertura de novas ruas ${ }^{9} \mathrm{Na}$ verdade, a intenção de destruição do bairro, preconizada através de um ideal de modernização, embelezamento e higienização da cidade, somente se efectivaria com o Estado Novo. Deste modo, sobretudo entre as décadas de 30-60, foi dada uma outra feição urbana àquela área da cidade, assistindo-se à destruição da parte baixa do bairro - antes composta por um entrelaçar de ruas, prédios antigos, igrejas, etc. Ao espaço vago ali deixado foi dado o nome de Largo do Martim Moniz, recuperando-se a lenda da reconquista cristã, o que ideologicamente era muito conveniente para a política do Estado Novo.

Pretendia-se fazer da Mouraria um bairro com avenidas largas, edifícios modernos e prestigiantes, remetendo para a periferia da cidade os moradores que poderiam comprometer um ideal de modernização e higienização. Entre as décadas de 70 e 80 do século Xx, o bairro e áreas adjacentes ainda seriam focos de interesse de políticas de modernização da cidade. Contudo, nos anos 80 do mesmo século, praticamente não se tinha edificado nos espaços deixados vagos pela destruição. Destaca-se nesta década a construção de um edifício para serviços e, mais tarde, a de dois centros comerciais: Centro Comercial da Mouraria e Centro Comercial do Martim Moniz.

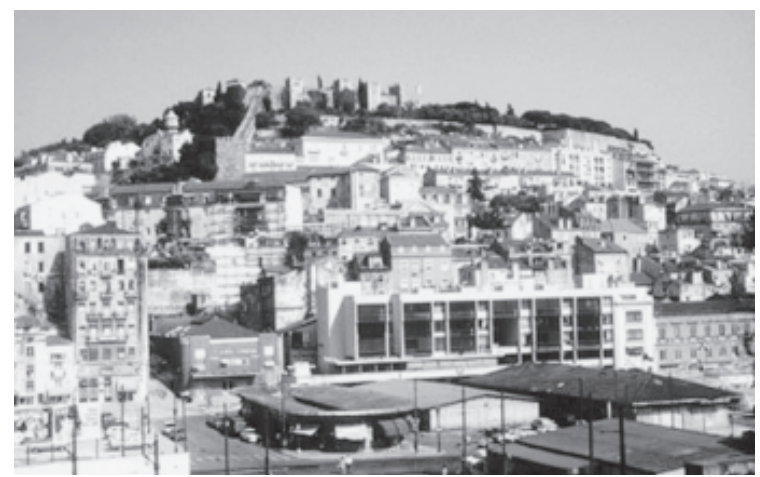

Largo do Martim Moniz em 1989

Foto de: Jaime Roseira

No entanto, face à degradação do parque edificado local, em muitos casos em risco de ruína iminente ou consumada - situação ainda mais agravada pela precariedade socioeconómica local e pela dificuldade de implantação de actividades que permitissem a dinamização económica e

\footnotetext{
9 Na parte baixa do bairro, destaca-se a criação da Rua Nova da Palma que, mais tarde, condicionou o sentido da Av. dos Anjos e da Av. Dona Amélia (de 1903, posteriormente designada como Av. Almirante Reis). Na parte alta da Mouraria, uma das principais alterações é a criação da Rua Marquês de Ponte de Lima e que permitiu ligar a Calçada dos Cavaleiros com a cidade intramuros, implicando assim a destruição de um troço da Cerca Fernandina.
} 
cultural da área - o bairro é, desde 1985, social e urbanisticamente, endógena e exogenamente, constituído como objecto de reabilitação urbana (Costa e Ribeiro, 1989; Costa, 1999). O processo de reabilitação urbana contribuirá para a reconstrução social da realidade simbólica e da imagem urbana do bairro. No âmbito deste novo ideal urbano, foi definido um conjunto de prioridades que primam pela valorização do património histórico-cultural a partir da demarcação de princípios orientadores e de regras que viabilizem a transmissão da herança histórica e a responsabilização dos diferentes actores sociais no processo de manutenção e conservação do património. Pelo que se visa "a fixação e melhoria das condições de vida dos residentes, proporcionando melhores condições de habitabilidade, reconvertendo e criando novos equipamentos. Pretende-se deste modo a revitalização económica, estimulando a população residente a participar neste processo global" 10 .

Importará notar que, desde a década de 70 do século $\mathrm{XX}$, se verifica naquela área da cidade a instalação de um comércio de revenda maioritariamente controlado por minorias étnicas. Tal fenómeno contribui para a configuração de uma outra imagem da Mouraria que, assim, passa também a ser referida como contexto multiétnico e multicultural, como lugar de pessoas, práticas, músicas, artefactos, roupas e comidas diferentes, que primam por uma certa diferença social e cultural. Locais como a Praça do Martim Moniz (construída em 1997) e o Centro Comercial da Mouraria são um dos principais palcos de visibilidade de tais dinâmicas. Nesta nova imagem ressoam algumas conotações associadas ao bairro enquanto espaço liminar, neste âmbito, como lugar de encontro de diferentes expressões culturais. A assumpção da Mouraria como uma espécie de símbolo do convívio multiétnico e/ou multicultural na cidade, convive com um outro universo de práticas e representações associadas a uma ideia do bairro como contexto de tradições populares ${ }^{11}$. Neste âmbito, importa no entanto não esquecer que, historicamente, os atributos de tipicidade popular associados à Mouraria, se encontram também vertidos numa imagem do bairro como espaço de pobreza e de transgressão, onde se desenvolvem actividades como a prostituição, o tráfico e o consumo de droga, e onde é possível encontrar sem-abrigo.

A Mouraria do presente pode ser descrita pela vivência de rua, as roupas estendidas nas janelas e pátios, as crianças a brincar, os edifícios históricos e degradados, as conversas à soleira da porta ou à janela, os homens a conversar nas esquinas, largos e travessas, as sardinhas a assar em braseiros colocados na rua; como também pela a procissão, pelos arraiais dos Santos Populares e a marcha popular ${ }^{12}$. Mas o presente do bairro pode também ser descrito através de um conjunto de territórios e dinâmicas que, para além de conjugarem os elementos mais características da sua população e mesmo do seu espaço físico, lida com novos e outros estilos de vida que não se explicam somente pelo fenómeno de gentrificação, nem pela heterogeneidade das classes populares, mas também por fenómenos de cariz étnico. Um mundo em que o fado, as severas e os marialvas, as tascas, as peixeiras, os operários, os (i)migrantes, os visitantes, os desempregados e os reformados coexistem com as lojas e mercearias chinesas, os cabeleireiros luso-africanos, os bazares indianos, a Associação Comercial China Town, o gang dos telemóveis, os toxicodependentes, os sem-abrigo. Tantas similaridades, tantos contrastes com a Madragoa, Bica e Alfama.

Recordada como um bairro mal frequentado, a Mouraria tem sido contada a partir das suas ruas estreitas e tortuosas, do seu casario característico, da boémia, da sina fadista e triste, da sua gente pobre e miserável, da Severa, dos jogos, da criançada nas ruas, configurando-se nesta perspectiva como uma

\footnotetext{
${ }^{10}$ Plano de Urbanização do Núcleo Histórico da Mouraria (PUNHM), 1996, Vol. 4: 1.

11 Neste sentido, importará assinalar, conforme refere Graça Cordeiro, que estas tradições, nos dias de hoje, diferenciam esses bairros e a sua gente dos outros locais e dos outros bairros da cidade por causa de uma herança cultural e vivencial que continua a "afirmar-se através de sistemas culturais locais (...) como se tivessem incorporado uma cultura local com traços de continuidade com o passado" (Cordeiro, 1995: $163,164)$.

12 A força simbólica das festas e rituais - como a marcha, o arraial popular e a Procissão de N. ${ }^{a}$ Sr. ${ }^{\text {a }}$ da Saúde - funcionam como mediadores simbólicos, facultando aos diferentes actores sociais a possibilidade de se identificarem e distinguirem dos outros, permitindo desse modo a introdução de vínculos de sentido social, bem como a continuidade e afirmação da Mouraria como um dos bairros típicos e tradicionais de Lisboa (Menezes, 2004).
} 


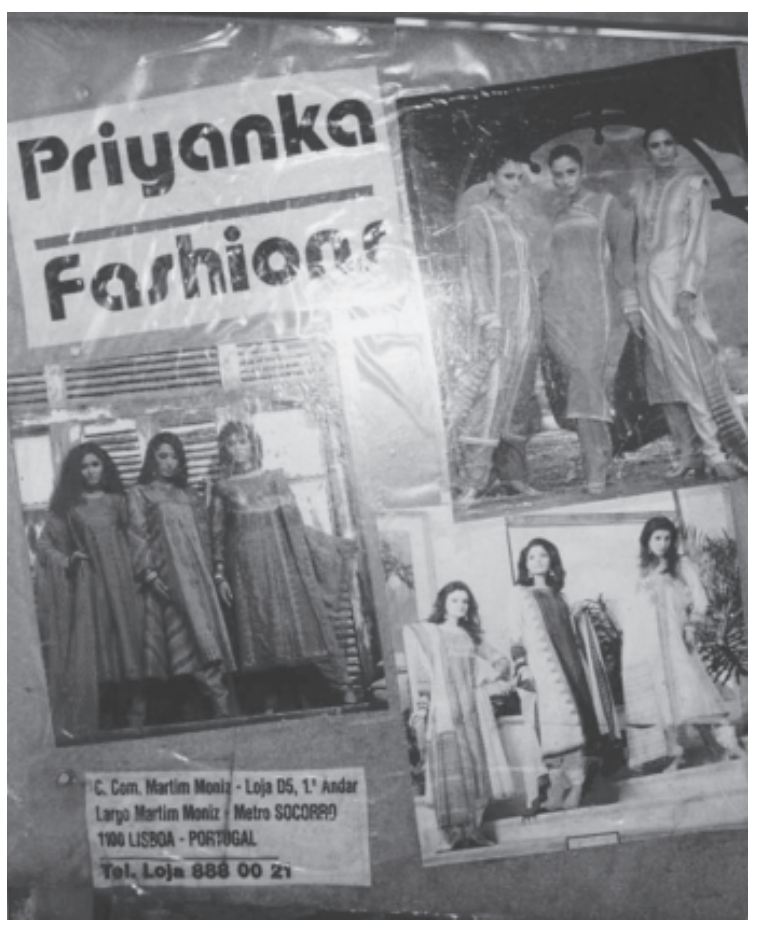

Publicidade numa montra de loja local Foto de: Marluci Menezes

espécie de primo pobre ${ }^{13}$ dos outros bairros populares da cidade. Imagens de um lado mais público e visível do bairro, que prevaleceram em

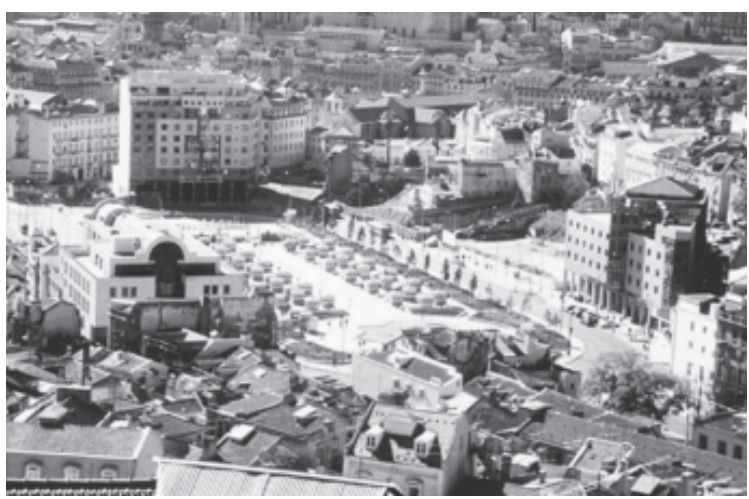

Vista da Praça do Martim Moniz a partir do Miradouro da Sr. ${ }^{\mathrm{a}}$ do Monte Foto de: Marluci Menezes alguns dos textos que evocaram a Mouraria na primeira metade do século Xx tendo, inclusivamente, justificado a promoção de um urbanismo civilizador que se reflectiu na política urbana do Estado Novo. Nos nossos dias, entretanto, o lado público e visível da Mouraria parece reflectir-se numa espécie de jogo de espelhos que reproduz imagens que transitam entre as ideia de típico, tradicional, popular, multicultural, multiétnico, mas também como um novo Casal Ventoso, Bronx e até Texas (Menezes, 2004) ${ }^{14}$.

\section{Um bairro com (con)tradições}

O largo inicialmente chamado de Martim Moniz foi transformado em praça em 1997, sendo igualmente baptizada com o nome do lendário soldado cristão ${ }^{5}$. Uma evocação, inclusivamente, materializada no planeamento e decoração estética da praça, onde se observa motivos e instalações alusivas ao troço da Cerca Moura, aos soldados cristãos que derrotaram os mouros e uma inscrição sobre a lenda de Martim Moniz ${ }^{16}$. Saliente-se que, desde a conclusão da praça, o local se tornou atractivo para muitos daqueles que diariamente frequentam a zona, destacando-se a presença quotidiana de indivíduos identificados com

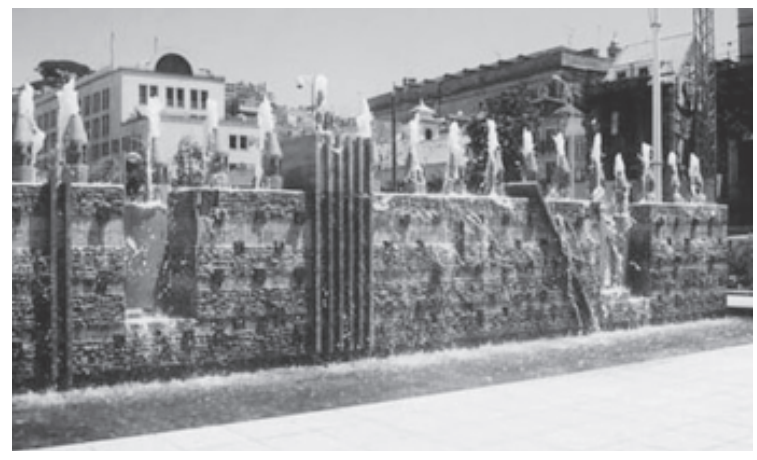

Muro alusivo à Cerca Moura (Praça do Martim Moniz) Foto de: Marluci Menezes

\footnotetext{
${ }^{13}$ Em diversas e variadas conversas com distintos indivíduos foi possível notar que, muitas vezes, o bairro da Mouraria era referido como sendo o primo pobre dos outros bairros típicos e populares da cidade, enquanto Alfama era referida como a menina dos olhos.

14 A notícia principal do jornal "A Capital" de 28.07.1999 foi: "Novo Casal Ventoso no Martim Moniz". A referência ao Bronx aparece no Jornal das Regiões de 02.04.2001 nos seguintes termos: "esses imigrantes, africanos, paquistaneses, indianos, moldavos e kosovares, que andam para aí em grupo, não tenho nada contra eles, mas nunca os vejo a trabalhar e quem não trabalha vive de quê? De negócios ilícitos. Qualquer dia fazem disso um Bronx!". Numa das entrevistas efectuadas com uma trabalhadora em um dos cabeleireiros locais, o bairro foi referido como parecendo "o Texas, pois há 23 anos é que era um paraíso".

15 A Praça do Martim Moniz já não faz parte da Área de Reconversão Urbana sob a responsabilidade do Gabinete de Reabilitação Urbana da Mouraria. A reconversão do Largo Martim Moniz em praça foi da responsabilidade da Câmara Municipal de Lisboa (CML), com projecto dos arquitectos Daniela Ermano e João Paulo Bessa, ambos da CML, e projecto de paisagismo da autoria do Arq. ${ }^{\circ}$ Gonçalo Ribeiro Teles.

${ }^{16}$ Para o Arq. ${ }^{\circ}$ José M. Fernandes, apesar da importância simbólica da construção da Praça do Martim Moniz, a opção estética que celebra o
} 
determinadas minorias étnicas que vivem (n)a cidade $^{17}$

No decorrer do processo de requalificação/ /reconversão do largo, o metropolitano também renovou a sua estação local e, após a conclusão das obras, a estação até então designada por Socorro, reabriu com uma nova designação: Martim Moniz. Esta remodelação implicou também uma renovação estética das plataformas dos comboios, entretanto decoradas com figuras que simbolizam a reconquista cristã da cidade, reforçando uma importância simbólica à lenda de Martim Moniz. Nos painéis de azulejo que decoram a entrada da estação foram colocados símbolos gráficos que aludem à presença de árabes, indianos e africanos por aquelas paragens. No meio destes símbolos gráficos aparece um painel de maior dimensão, de autoria de Gracinda Candeias, com a seguinte inscrição:

"Socorro - topónimo com raiz na antiga Igreja do Socorro - dá nome a um lugar que ao longo dos séculos foi constituindo interessantíssimo ponto de encontro de culturas diversas e de vivências múltiplas. Desde a presença de árabes, que estará na origem da designação popular "Mouraria", até aos indianos e africanos. / Foram escolhidos três temas para representar, de forma iconográfica, três tempos históricos que simbolizam a convergência destas múltiplas culturas. (...) Gracinda Candeias - Lisboa, 1995 / 97."

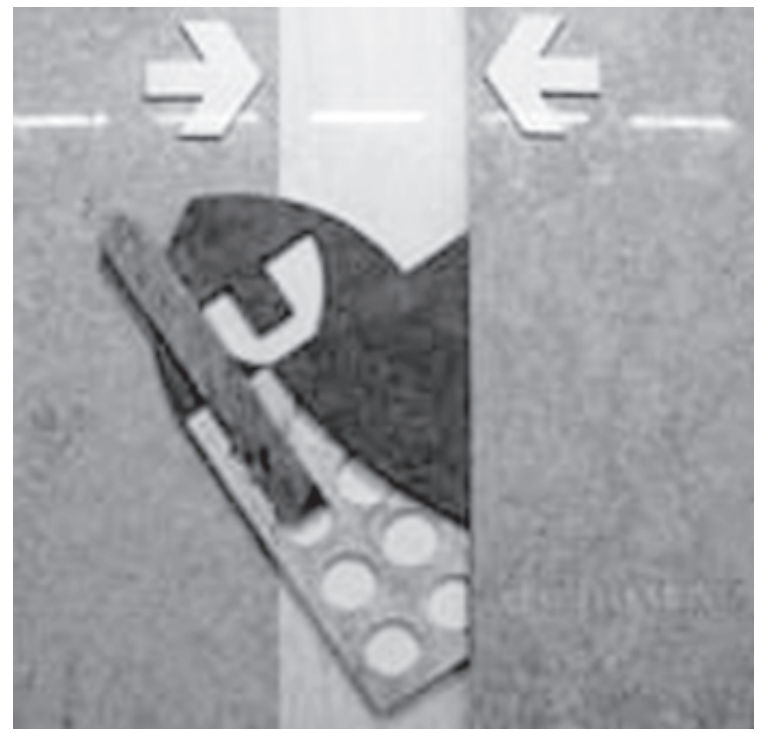

Martim Moniz e D. Afonso Henriques (conforme representação existente na plataforma de embarque da estação de metro do Martim Moniz) Foto de Marluci Menezes

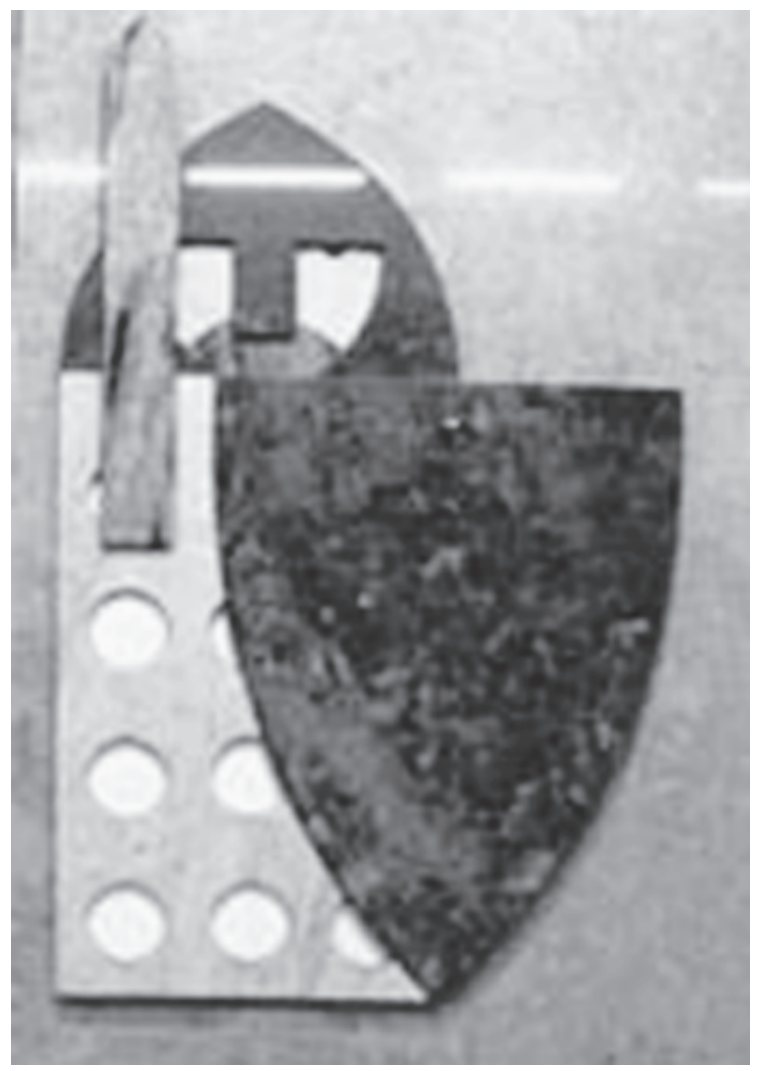

“mártir da conquista de Lisboa, o Martim Moniz (...) é um pouco descritiva demais (as portas, os guerreiros, etc.) )revista do semanário Expresso, 07.02.1998).

17 Antes da construção da Praça do Martim Moniz, o ponto de encontro privilegiado por estes indivíduos localizava-se na Rua da Mouraria, por detrás do Centro Comercial da Mouraria. Curiosamente, este local é ponto de encontro dos moradores mais antigos do bairro, sobretudo os homens, desde há muitos anos. Importa salientar que a inauguração da Praça do Martim Moniz desencadeou um interesse generalizado por entre os moradores mais antigos do bairro que ali iam passear e deixarem-se estar. No entanto, paralelamente ao aumento de minorias étnicas na praça, diminuiu a presença dos moradores mais antigos que, desde então, sobretudo utilizam a praça como lugar de atravessamento, excepção feita aos momentos fora do quotidiano, como é o caso das festas e arraiais populares e do período de comemoração relacionado com a Procissão da Nossa Senhora da Saúde, quando dois momentos se destacam: a realização da missa campal passou a ser realizada nesta praça e o percurso da procissão tem início na sua proximidade imediata (Menezes, 2004). 
Neste pequeno relato da história da freguesia do Socorro, onde se insere o núcleo central da Mouraria, repare-se a evocação a três culturas e tempos: árabe, indiano e africano. Note-se que o recurso ao termo árabe retira, premeditadamente (ou não), qualquer conteúdo ou conotação pejorativa que a designação Mouraria originalmente comporta: inicialmente, mouraria designava o espaço segregado para os mouros vencidos que não saíram da cidade. Esta imagem pública, construída entre uma mescla de mitos e realidade, parece esbater toda a sua má reputação, associada à sina fadista. Nos elementos de decoração da estação do metropolitano e da praça não se vislumbra a inspiração nesta outra faceta do bairro.

Em que medida nos encontrarmos em presença da invenção de novos símbolos que procuram explicar o presente, neste caso, evitando o recurso à socioecologia do mundo do fado, isto é, sem a peculiaridade popular, sem a miséria e sem vícios? A bondade com que é assumida a faceta multicultural local parece ser uma das imagens mais evocadas por essa tentativa de reemblematização da Mouraria. De que modo este reposicionamento do bairro olhado como entreposto de culturas tende a ignorar as suas outras especificidades culturais locais?

À época da realização da pesquisa, a Câmara de Lisboa publicara roteiros temáticos de passeio pela cidade, os quais eram distribuídos gratuitamente nos postos de turismo da municipalidade. Num destes roteiros, intitulado "Lisboa, Cidade de Exílios", a antiguidade medieval do convívio multiétnico da Mouraria surge como porta de entrada a um percurso por uma Lisboa designada "de todas as cores" (Agualusa, 1999: 9) ${ }^{18}$ :

"Em 1147, D. Afonso Henriques, primeiro rei de Portugal, conquistou aos Árabes a cidade de Lisboa. Um dos fidalgos que o acompanhavam, Martim Moniz, impediu o encerramento de uma das principais portas do castelo utilizando o próprio corpo como obstáculo. A história não o esqueceu. Em pleno coração de Lisboa uma praça guarda o seu nome. / Foi a partir desta praça, entalada entre duas colinas, que se formou pouco a pouco o Bairro da Mouraria. O local ganhou essa designação depois da conquista (...)." (idem)

Apesar de algumas imprecisões contidas no fragmento acima citado (a mais evidente das quais será o facto de que a Mouraria não tem a sua origem a partir da praça actualmente chamada Martim Moniz), o seu interesse justifica-se por nos auxiliar a compreender alguns dos elementos convocados para a construção de uma determinada imagem do bairro. Novamente, destaca-se a ideia da conquista da cidade aos mouros, a demarcação da origem da multietnicidade com a reconquista cristã e a demarcação da origem da Mouraria a partir da praça que, entretanto, recebeu o nome do lendário soldado.

No roteiro acima referido é ainda estabelecida uma relação entre a expansão portuguesa e o aparecimento dos africanos e indianos em Lisboa. Situado, segundo o autor, no bairro "dos últimos árabes de Lisboa", a referência ao Centro Comercial da Mouraria é feita nos seguintes termos:

"Lá dentro, numa única tarde, pode-se visitar quase todo o antigo Império Português. A fragrância forte das especiarias enlouquece o ar. Inevitavelmente vem-nos à memória a grande aventura dos Descobrimentos Portugueses: foi para renovar o fatigado sabor da culinária europeia que Vasco da Gama se lançou ao mar, em direcção à Índia, inaugurando uma nova rota comercial, e mudando assim os destinos do mundo.

Distribuídas por quatro andares do Centro Comercial da Mouraria encontram-se diversas lojas de produtos africanos, chineses e indianos. (...) diversos cabeleireiros africanos, alfaiates congoleses, restaurantes chineses, indianos e africanos, casas de artesanato e discotecas especializadas em world music." (Agualusa, 1999: 20-21)

O elemento mouro é positivamente considerado, sendo deixada de lado a ideia de vencido que usualmente lhe estava associada. Na verdade, de novo se reforça a ideia de transfiguração do significado histórico da designação mouro que, ao abarcar também uma maior amplitude, interessantemente, irá permitir a aproximação com o universo de além-mar, o mundo ultramarino das descobertas portuguesas, com os aromas e cores também trazidos pelos indianos e africanos, seguidos dos

\footnotetext{
18 Os três primeiros títulos publicados no âmbito desta iniciativa foram: "A Lisboa de Saramago" (Alves, 1999); "Lisboa nos Passos de Pessoa" (Dias, 1999); "Lisboa, Cidade de Exílios" (Agualusa, 1999). Após esses primeiros títulos, foram publicados três outros roteiros: "Lisboa, passagem de poetas e escritores estrangeiros" (Feijó, 2000); "Lisboa. Pepe de Carvalho na cidade dos espiões e heróis" (Montálban, 2000); "Lisboa de Alves Reis" (Mota, 2000). Portanto, à excepção do roteiro pela cidade colorida das etnias, todos os outros especificam a relação entre determinadas personalidades e a cidade. Nesse sentido, salienta-se a particularidade do roteiro sobre a cidade de todas as cores, no sentido em que, a par da existência de diferentes etnias na cidade, ele permite corroborar uma ideia de construção de um campo de significações de um imaginário da cidade que se fundamenta na positivação da multietnicidade e do pluralismo. Por outro lado, curiosa será a tradução da ideia de uma "Lisboa de todas as cores", expressa no roteiro pela expressão United Colours of Lisbon (Agualusa, 1999).
} 
chineses. Nesta sucessão de apropriações e transformações da história local, e da sua intersecção com momentos históricos que, inclusivamente, são fundamentais para a invenção da própria identidade nacional, verifica-se uma importante estratégia simbólica de positivação da imagem do outro, assim transformado num dos símbolos do bairro da Mouraria. Em nós ressoa a interrogação: por onde passa, na reconversão urbana, a requalificação da própria história?

Observe-se, a propósito, o discurso de um técnico ligado ao processo Reconversão Urbanística da Mouraria, contactado durante a pesquisa de terreno:

"Para além da especificidade tradicional que tem a ver com a cultura lisboeta, alfacinha e bairrista, onde o fado e as relações de vizinhança estão presentes, existe essa mistura. (...) A principal potencialidade do bairro da Mouraria é a multietnia e a multi-racialidade, é uma tradição, tem a ver já anteriormente quando os mouros foram expulsos para aqui, houve uma mistura racial dos próprios cristãos com os mouros, com os povos vindos do Norte, etc. Ela continua agora com os africanos e continua com os asiáticos, e portanto, eu diria que se Lisboa é um pouco a Kashba da Europa, a Mouraria também o é de Lisboa. Mouraria é um pouco Kashba. Encontra-se restaurante africano, encontra-se o sítio onde há música africana especial, não é aquela comercializada nos compactos. (...) Existem certas especificidades a nível de bijutaria, a todos os níveis, até poderá ser paralela com as importações que os próprios asiáticos fazem dos seus países de origem. Isto é um entreposto comercial, onde muita gente vem comprar, do Norte, do Sul, de Espanha, Madrid, muitos comerciantes de Madrid, a nível da bijutaria, são os clientes preferenciais das lojas da Mouraria. Portanto, eu penso que esse é o potencial principal e a sua especificidade." (Menezes, 2004: 251).
Importará notar que a defesa estratégica do bairro como local de tradição multiétnica, não se constrói inteiramente pela negação e/ou ocultação de uma "cultura lisboeta, alfacinha e bairrista". Tal cultura, associada às práticas vindas do passado, assume-se como atributo que, para alguns, importa revitalizar na sua genuinidade ${ }^{19}$.

\section{Algumas interrogações sobre a recuperação das tradições}

Emblematizado como bairro popular e típico de Lisboa, referenciado pelo seu pitoresco e peculiaridade cultural, a Mouraria foi também, ao longo da história das intervenções urbanas que nela tiveram lugar, contraditoriamente repelida por essas mesmas características, entretanto, exacerbadas enquanto vícios, crimes, insalubridade e sintomas de incivilidade e atrofiamento urbano. Convertidos em elementos de tipicidade e tradição, estes temas assumem-se como filão para auto-representação do bairro em manifestações como arraiais e marchas populares da cidade. Como articular estas dinâmicas com a invenção da multiculturalidade e multietnicidade como marcas da especificidade local - sendo que através dessas últimas imagens parece proceder-se a um aparente esbatimento dos processos de emblematização e estigmatização que também atravessam o bairro?

Como refere Márcia Fantin (2000:144), ao pensar-se criar ou recriar tradições é necessário muito mais do que somente "ter" e "executar" uma ideia. Isto porque, uma tradição inventada "precisa não só ter uma certa cara mas ser capaz de produzir motivações e emoções sintonizadas com os desejos de um certo colectivo." Neste sentido, colocam-se algumas inquietações. Uma dessas inquietações, reporta-se às interpretações que tomam a imagem de multiculturalidade local como sinónimo de

\footnotetext{
19 Observa-se que o técnico acima referenciado, sugeriu também a importância de "revitalizar as tradições" porque a "originalidade" de determinadas manifestações culturais lisboetas "se estava perdendo". Este técnico mostrava-se decepcionado com o facto de a "genuinidade" na organização dos arraiais populares da cidade já não existir, desse modo indiciando uma espécie de nostalgia que tinha relativamente à autenticidade das "tradições passadas" e que, segundo ele, se foram perdendo com a transformação dos arraiais em negócios lucrativos. Na página da NET do Partido Socialista (PS) sobre Autarquias (http://www.partido-socialista.pt/accao/01/1112_07_06_2001/Autarquias.html), vem referido uma notícia sobre um megaprojecto para a Mouraria da responsabilidade do Gabinete Local, sendo salientado que um dos principais objectivos desse projecto é "potenciar a maior riqueza da zona: a diversidade étnica" e, para tal, pretendem: "transformar fachadas e lojas, fechar algumas ruas ao trânsito, criar percursos exclusivamente pedonais e pensar em novas formas de organizar o estacionamento (...) (...) Depois de um encontro entre alguns membros da autarquia lisboeta e responsáveis das diversas etnias, o gabinete começou a fazer os inquéritos à população local para a envolver no processo. A ideia-chave é associar as regras arquitectónicas e urbanísticas da Mouraria à diversidade étnica da sua população. 'Queremos fazer algo na zona que esteja de acordo com quem a vai utilizar. Os comerciantes e moradores locais têm uma palavra a dizer", conforme referiu o responsável pelo Gabinete. Na continuidade da notícia vem ainda referido que "no final dos inquéritos, que deverão terminar em Dezembro deste ano, o Gabinete avança com os projectos de planificação do espaço comercial no sentido de o transformar de forma a espelhar as diversas etnias que ali se reúnem todos os dias. 'A especificidade da Mouraria é uma riqueza que devemos potenciar e não esconder", acrescentou o responsável pelo Gabinete". Mais ao fim da notícia é, então, observado que “a encosta da Mouraria foi, desde sempre, coabitada por cristãos, mouros e judeus (...)".
} 
convívio inter-étnico ou de integração social e urbana. Uma segunda inquietação advém do facto de que a preponderância conferida a uma imagem multicultural parece processar-se não valorizando alguns dos meios, espaços e instrumentos de mediação cultural, social e simbólica que, a priori, já existem no local. Em terceiro lugar, é importante considerar que, a par da positivação em torno da imagem do outro e do próprio processo que reproduz a imagem da tipicidade popular do bairro, não se deve esquecer que tanto uma com ao outra imagem são atravessadas por lógicas de exclusão, segregação e estigmatização socioespacial (Menezes, $2004)^{20}$. Importa, como tal, ao nível da intervenção urbana investigar e promover formas de mediação entre o carácter popular e típico do bairro e o seu carácter multiétnico, para que a salvaguarda e a reabilitação do património se articule com a promoção do desenvolvimento socio-urbanístico ${ }^{21}$. De outra forma, o bairro poderá ver reforçado as dinâmicas que, ao longo da sua história, propiciaram o desenvolvimento de processos de segregação socioespacial. Neste âmbito importará ter em atenção quatro riscos:

- Ignorar a heterogeneidade dos territórios e a diversidade das dinâmicas culturais que constroem a Mouraria - considerando o bairro como um todo homogéneo.

- Atender a tal heterogeneidade, mas tomar as parcelas de diversidade como factores independentes e mutuamente exclusivos - não olhando às interpenetrações quotidianas entre partes.

- Reduzir a ideia de heterogeneidade sociocultural à diversidade de expressões étnicas - obscurecendo a importância, não apenas de outras fontes de heterogeneidade social, como também dos processos de recomposição de práticas e representações identitárias múltiplas.

- Fazer prevalecer, em termos de valorização patrimonial, umas parcelas em detrimento de outras - (de certo modo) promovendo o zonamento das tradições a par de sobrepor determinadas identidades culturais à determinados territórios.

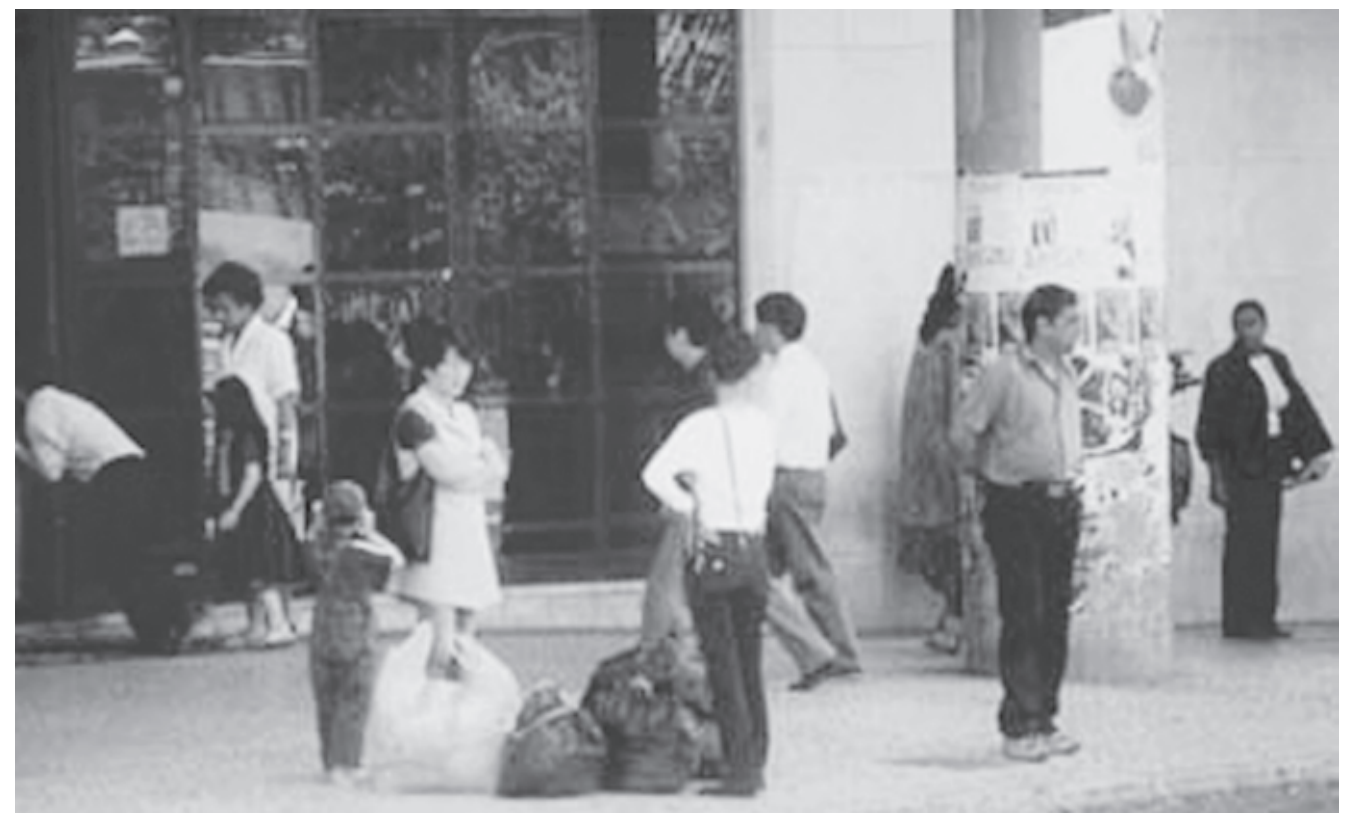

A espera... (entrada do Centro Comercial da Mouraria)

Foto de: Marluci Menezes

\footnotetext{
$\overline{20}$ A espacialização do poder, como refere Davina Cooper (1998), não implica necessariamente a exclusão dos indivíduos dos espaços públicos, podendo antes desenvolver-se através do zonamento de certas áreas urbanas. Isto é, indivíduos e práticas passam a estar associados a um determinado espaço, fazendo coincidir as ideias de identidade cultural com as de identidade territorial, entretanto, e com base em certos mitos, imagens e conotações atribuídas a essas mesmas práticas. A autora salienta ainda que uma das estratégias de espacialização do poder inclui a mudança ou a introdução de novos ícones para a celebração de sinais tidos como pluralistas ou progressistas. A pertinência dessa observação é particularmente recorrente para pensar a remodelação da estação do metropolitano, bem como a decoração adoptada aquando da construção da praça designada por Martim Moniz. A instituição de tais estratégias viabilizam a transformação da identidade cultural do espaço, de forma responder a pretensões de uma sociedade mais ampla que se prendem com a necessidade de inclusão, mas também controlo, de grupos e indivíduos socialmente marginalizados.

${ }^{21}$ Na discussão que Abel Albet i Mas $(2004,23)$ desenvolve sobre a utilização da cultura no âmbito da definição das estratégias de transformação socio-urbanísticas da cidade de Barcelona, o autor chama a atenção para "a aparente aposta numa cidade multicultural que não deixa de ser senão uma imagem funcional para evitar o conflito e banalizar as diferenças".
} 


\section{O que salvaguardar e como reabilitar?}

Neste texto pretendeu-se evocar a importância de abordar, analisar e avaliar a perspectiva de salvaguarda e reabilitação do património urbano, a partir de um enfoque mais amplo, de modo a não se restringir as propostas de salvaguarda, protecção e/ou reabilitação apenas a determinados aspectos ou atributos socioculturais.

Admitindo que as tradições existem, conforme observado por Hobsbawm e Ranger (1996), estas são também, em cada momento de cada presente histórico, resultado de processos continuados de configurações e reconfigurações. Uma tradição pode ser também manipulada de forma a corresponder aos interesses de uma dada sociedade ou de determinados interesses económicos ou políticos.

É questionável tentar revitalizar determinadas práticas socioculturais (ou explicar o porquê da perda de determinados saberes, práticas e valores) através da ideia de que antes havia uma originalidade (ou uma genuinidade) a que importa regressar, recuperando, conservando ou reabilitando. Destas intenções resultam dois aspectos, não raras vezes subvalorizados, nomeadamente: definir melhor o que é (ou se é) possível confirmar a existência de uma genuinidade passada; analisar e avaliar melhor os impactes existentes no processo de conversão de determinados bens ou manifestações culturais em referentes identitários dos contextos. Repare-se, como observado por Vasconcellos e Mello (2006: 63), que "o re é uma estratégia que considera (ou finge considerar) a inclusão do tempo na análise do espaço, sem, contudo, explicitar um significado e uma metodologia para tal".

Os processos de salvaguarda e reabilitação socio-urbanística podem assumir-se como uma oportunidade de potencial inversão das situações de desfavorecimento social, económico e habitacional das populações, bem como da promoção activa e interactiva de dinâmicas de valorização sociocultural dos contextos de intervenção. Desta forma, defende-se que a promoção de uma lógica de salvaguarda, reabilitação e revitalização do património, deve trabalhar de forma interrelacionada:

- Os indivíduos/grupos: a população residente e utente dos locais, trabalhando-as transversalmente, na heterogeneidade das suas práticas e características socioculturais e demográficas.
- Os espaços: à vizinhança próxima e alargada, reconhecendo as diversas interconexões entre privado e público olhando aos interstícios e aos espaços de transição (da casa ao pátio, do pátio à rua, da rua ao largo, do largo à praça, ao jardim, ao teatro, à fábrica, ao local de consumo, e/ou públicos, privados, semi-públicos, intermédios, de transição, vizinhança próxima e alargada...).

- Os vários âmbitos mobilizados e tocados pela intervenção, promovendo-se a atenção mútua e a integração das vertentes físicas, sociais, culturais, históricas, económicas.

- Os estudos: as pesquisas produzidas nas diferentes vertentes disciplinares, reconhecendose e cultivando-se a diversidade dos saberes inerente à complexidade do real.

- As intervenções preexistentes: a valorização e a reflexão crítica sobre a experiência acumulada.

- Os diagnósticos de caracterização e de avaliação elaborados numa perspectiva dinâmica, relacional e flexível, com capacidade de articulação disciplinar/dimensional, desse modo reflectindo sobre as relações entre cultura e sociedade, dinâmicas de degradação, segregação e exclusão socio-espacial, auxiliando-nos a identificar, definir e escalonar não apenas a procedência, o sentido e o carácter social dos problemas que afectam a realidade social, como também os recursos e potencialidades que também compõem essa mesma realidade.

- Os projectos como expressões culturais, fenomenológicas e pragmáticas, que contribuem para a invenção/criação de novas dinâmicas socioespaciais/urbanísticas.

Não se pretende pôr em causa a boa intenção e a legitimidade do trabalho dos muitos actores institucionais e técnicos que intervém na cidade existente. Não se pretende também dar receitas mágicas, mas lançar pistas de reflexão que acautelem a adesão a propostas que possam revestir-se desse carácter. Desde logo, porque os impactes na realidade social e urbana nem sempre são imediatos, podendo em alguns casos, criar ou acentuar problemas que, eventualmente, poderiam ter sido evitados ou minimizados, caso se trabalhasse, por um lado, mais directamente com as populações e, por outro lado, caso se investisse no desenvolvimento de programas e projectos de salvaguarda e reabilitação que contemplassem, eficazmente, diferentes frentes disciplinares de 
forma a abranger as várias e múltiplas dimensões da realidade socio-ecológica.

Não se entende as perspectivas de salvaguarda ou de reabilitação do património como necessariamente opostas à ideia de dinâmica social. Acredita-se que, sobretudo, importa não restringir o sentido da noção salvaguarda à simples ideia de perpetuar alguma coisa, alimentando uma perspectiva de imobilidade perante a história e perante a própria ideia de construção de identidade(s). Neste sentido, é interessante a perspectiva sobre a autenticidade como a capacidade que as sociedades têm para escolher livremente como querem viver o presente sem renunciarem às suas histórias e culturas. Em síntese, estes aspectos são fundamentais por dois motivos: permitem a salvaguarda do património e viabilizam uma melhor adaptação às novas necessidades (Moragas, 2001). Neste sentido, importará conceber as intervenções como um factor de desenvolvimento da sociedade, nas quais a História seja entendida como um processo, e não unicamente designe algo que decorre da variável tempo significando com isso passado (Torrico, 1997).

Como sublinha José Gonçalves (2005, 32), "os actuais discursos (e políticas) de património cultural talvez possam assumir formas menos omnipotentes, interrompendo-se o esforço obsessivo de objectificação ou naturalização dos patrimónios na medida mesma em que esses discursos são expostos ao reconhecimento da natureza necessariamente ambígua e precária dos objectos que simultaneamente representam e constituem". Interessa pois investir no conhecimento, identificação e avaliação dos níveis de significação desses mesmos elementos, o que remete para a necessidade de olhar com mais atenção uma determinada trama cultural (Torrico, 1997). 


\section{Bibliografia}

AGUALUSA, José Eduardo, 1999, Lisboa, Cidade de Exílios, Lisboa, Câmara Municipal de Lisboa.

AGUIAR, José, 1993, “Dificuldades na Reabilitação do Património em Portugal"; Comunicação apresentada na Conferência Internacional "Reabilitação dos Centros Históricos e sua Dinamização", Lx (doc. policopiado).

BARROS, Maria F. Lopes de, 1998, A Comuna Muçulmana de Lisboa: sécs. XIV e XV, Lisboa, Biblioteca de Estudos Árabes: Hugin.

BARTHES, Roland, 1987, Mitologias, São Paulo, Difel.

BOURDIN, Alain, 1979, "Restauration / Réhabilitation: l'ordre symbolique de l'espace néo-burgeois", Espace et Societé, n. ${ }^{\text {os }}$ 30-31, Paris, pp. 15-35

BOURDIN, Alain, 1984, Le Patrimoine Réinventé, Paris, PUF.

BOURDIN, Alain, 1996, "Sur quoi fonder les politiques du patrimoine urbain? Professionnels et citoyens face aux témoins du passé", Les Annales de la Recherche Urbaine, n. ${ }^{\circ}$ 72, Paris, pp. 7-13.

CASAL, Yañez, 1994, “Arqueologia, Antropologia e Património", Ethnologia, n. ${ }^{\text {os }}$ 1-2, Lisboa, Departamento de Antropologia da UNL.

CHOAY, Françoise, 1992, L'Allégorie du Patrimoine, Paris, Ed. Seuil.

COOPER, Davina, 1998, "Regard between strangers: diversity, equality and the reconstruction of public space", Critical Social Policy, Vol. 1814, London, pp. 465-492.

CORDEIRO, Graça Índias, 1997, Um Lugar na Cidade: Quotidiano, Memória e Representação no Bairro da Bica, Lisboa, Publicações Dom Quixote.

CORDEIRO, Graça Índias, 1995, Um Bairro no Coração da Cidade: Um Estudo Antropológico sobre a Construção Social de um Bairro Típico de Lisboa, Lisboa, ISCTE (tese de doutorado).

COSTA, A. Firmino da, 1999, Sociedade de Bairro, Oeiras, Celta Editora.

COSTA, A. Firmino da. RIBEIRO, Manuel João, 1989, "A construção social de um objecto de reabilitação", Sociedade e Território, n. ${ }^{\text {os }}$ 10-11, Lisboa, pp. 85-95.

FANTIN, Márcia, 2000, Cidade Dividida: Dilemas e Disputas Simbólicas em Florianópolis, Florianópolis, Ed. Cidade Futura.

FERNANDES, José Manuel, 1998, “Martim Moniz: finalmente a praça", Lisboa, Revista do Semanário Expresso de 07.02.1998.

FORTUNA, Carlos, 1997, "Destradicionalização e imagem das cidades", in FORTUNA, Carlos (org), Cidade, Cultura e Globalização, Oeiras, Celta Editora, pp. 231-258.

FORTUNA, Carlos, 1999, Identidades, Percursos, Paisagens Culturais, Oeiras, Celta Editora.

FORTUNA, Carlos; PEIXOTO, Paulo, 2002 "A recriação e reprodução de representações no processo de transformação das paisagens urbanas de algumas cidades portuguesas", in FORTUNA, Carlos; SANTOS SILVA, Augusto (orgs.), Projecto e circunstância. Culturas urbanas em Portugal, Porto, Afrontamento, pp. 17-63.

FORTUNA, Carlos; PEIXOTO, Paulo, 2002 "As novas e velhas imagens das cidades: um olhar sobre a transformação identitária de cinco cidades portuguesas", Actas do IV Congresso Português de Sociologia, Oeiras, Celta Editora (CDROM).

FRIAS, Aníbal; PEIXOTO, Paulo, 2002, "Representação imaginária da cidade. Processos de racionalização e de estetização do património urbano de Coimbra", Oficina do CES, n. ${ }^{\mathrm{o}}$ 183, Coimbra.

GONÇALVES, José Reginaldo Santos, 1988, "Autenticidade, Memória e Ideologias Nacionais: o problema dos patrimónios culturais"; Estudos Históricos, Rio de Janeiro, Vol. 1, n. ${ }^{\circ} 2$, pp. 264-275.

GONÇALVES, José Reginaldo Santos, 2002, "Monumentalidade e cotidiano: os patrimônios culturais como género de discurso", in LIPPI OLIVEIRA, Lúcia, 2002, Cidade: História e Desafios, Rio de Janeiro, FGV, pp. 108-123.

GONÇALVES, José Reginaldo Santos, 2005, "Ressonância, materialidade e subjectividade: as culturas como patrimónios"; Horizontes Antropológicos, Porto Alegre, ano 11, n. ${ }^{\circ}$ 23, pp. 15-36.

GUILLAUME, Marc, 1980, La Politique du Patrimoine, Paris, Éditions Galilée.

HOBSBAWM, Eric, e Terence RANGER (orgs.), 1996, The Invention of Tradition, Cambridge, University Press.

JACQUES, Paola Berenstein, 2003, "Património cultural urbano: questões contemporâneas", Actas do $3 .^{\circ}$ ENCORE Encontro sobre Conservação e Reabilitação de Edifícios; Vol. 2. Lisboa: LNEC, pp. 703-710.

JEUDY, Henri Pierre (org.), 1990, Patrimoines en Folie, Paris, Éditions de la Maison des Sciences de l'Home.

MAS, Abel Albet, 2004, "La cultura en las Estratégias de Transformación Social Urbanística de las Ciudades. Barcelona, del Modelo al Espectáculo, Cidades, Comunidades e Territórios, n. ${ }^{\circ}$ 9, Lisboa, CET, ISCTE, pp. 15-25.

MENEZES, Marluci, 2004, Mouraria, Retalhos de um Imaginário: significados urbanos de um bairro de Lisboa, Oeiras, Celta Editora.

MORAGAS, Carlos Romero, 2001, "Ciudad, cultura y turismo: calidad y autencidad, PH: Boletín del Instituto Andaluz del Patrimonio Historico", Año IX, n. ${ }^{\circ} 36$, Sevilla, Instituto Andaluz del Patrimonio Historico, Septiembre.

OLIVEN, Ruben, 1992, A Parte e o Todo: a Diversidade Cultural no Brasil-Nação, Petrópolis, Vozes.

Plano de Urbanização do Núcleo Histórico da Mouraria, 1996, Lisboa, CML, DMRU.

PORTAS, Nuno, 1985, “Notas sobre a Intervenção na Cidade Existente", Sociedade e Território, Ano 1, n. ${ }^{\circ}$ 2, Lisboa, pp. 8-13.

TORRICO, Juan Agudo, 1997, “Patrimonio Etnológico: problemática en torno a su definición y objetivos", PH: Boletín 
del Instituto Andaluz del Patrimonio Historico", Año IX, n. ${ }^{\circ} 36$, Sevilla, Instituto Andaluz del Patrimonio Historico, pp. 97-108.

VALENTE PEREIRA, Maria da Luz (1986). Reabilitar o Urbano ou como Restituir a Cidade à Estima Pública. ITE 16, Lisboa, LNEC.

VARGAS, Heliana Comin; CASTILHO, Ana L. Howard, 2006, "Intervenções em centros urbanos: objectivos, estratégias e resultados", VARGAS, Heliana Comin; CASTILHO, Ana L. Howard (orgs.), 2006, Intervenções em Centros Urbanos Objectivos, estratégias e resultados. São Paulo. Editora Manole, pp. 1-52.
VASCONCELLOS, Lélia Mendes de; MELLO, Maria C. Fernandes, 2006, "Re: atrás de, depois de...", VARGAS, Heliana Comin; CASTILHO, Ana L. Howard (orgs.), 2006, Intervenções em Centros Urbanos - Objectivos, estratégias e resultados, pp. 53-66.

VAZ, Lilian Fessler, 2004, "A culturalização do planejamento e da cidade - novos modelos?"; Territórios Urbanos e Políticas Culturais, Cadernos PPG-AU/FAUNA, número especial, Salvador, Universidade Federal da Bahia, pp. 31-42.

VILARES, Elisa, 2003, "Back to the City: O discurso e as metodologias da Regeneração Urbana", Cidades, Comunidades e Territórios, n. ${ }^{\circ}$ 7, Lisboa, CET-ISCTE, pp. 100-109. 